\title{
Incubation temperatures, hatching success and congenital anomalies in green turtle nests from Guanahacabibes Peninsula, Cuba
}

\author{
Randy CALDERÓN PEÑA ${ }^{1}$, Julia AZANZA RICARDO
}

Cite this article as:

Calderón Peña, R., Azanza Ricardo, J. (2021). Incubation temperatures, hatching success and congenital anomalies in green turtle nests from Guanahacabibes Peninsula, Cuba. Aquatic Research, 4(4), 321-330. https://doi.org/10.3153/AR21027

${ }^{1}$ University of Havana, Faculty of Biology, - 25 \# 10, CP 10400, Plaza, Ciudad Habana, Cuba

${ }^{2}$ University of Havana, Higher Institute of Technologies and Applied Sciences, Avenida Salvador Allende 1110, Quinta de los Molinos, , CP 10400, Plaza, Ciudad Habana, Cuba

\section{ORCID IDs of the author(s):}

R.C.P. 0000-0001-7712-2944

J.A.R. 0000-0002-9454-9226

Submitted: 15.12 .2020

Revision requested: 13.02 .2021

Last revision received: 25.03 .2021

Accepted: 25.03.2021

Published online: 20.05.2021

Correspondence:

Julia AZANZA RICARDO

E-mail: julia dragmarino@yahoo.es

\section{ABSTRACT}

Elevated incubation temperatures of sea turtle nests decrease hatching success and alter the resulting hatchlings' morphology. There is an absence of studies assessing the relationships between temperature and hatching success in Cuba, even when they could improve understanding the limits of thermal tolerance in these species. This study evaluated the influence of incubation temperature on hatching success and phenotypic malformations in green turtle hatchlings (Chelonia mydas); and analyzed the temporal variation in hatching success on the studied beaches. In 48 green turtles nests distributed along two beaches, incubation temperature and hatching success were recorded between 2014 and 2019. Increasing incubation temperature caused a decrease in the hatching success and an increase in the frequency of supernumerary scutes. Despite the elevated temperatures (average $>30^{\circ} \mathrm{C}$ ), hatching was higher than $80 \%$. Significant differences in hatching success were only observed among seasons for nests in Antonio Beach (lower values in 2016 and 2019 compared to 2014).

Keywords: Marine turtles, Climate change, Temperatures, Hatching success, Phenotypic malformations

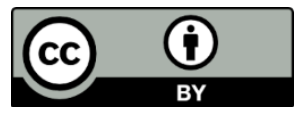

(C) 2021 The Author(s) 


\section{Introduction}

In the last century, an excessive increase in the global temperature has been observed (IPCC, 2018). This increase endangers many species; including sea turtles, because it affects hatchlings' phenotype (Glen et al. 2003), hatching success (Broderick et al., 2001; Weber et al., 2012) and sex proportion (Laloë et al., 2016).

The maximum thermal limit for successful incubation is not adequately defined (Howard et al. 2014); assessing this value allows identifying sea turtle populations at risk of embryonic mortality due to possible increases in global temperatures. For green turtles, Miller (1997) defined a temperature of $33^{\circ} \mathrm{C}$ as the maximum thermal limit for hatching to occur, while Weber et al. (2012) reported at a temperature of $33.4^{\circ} \mathrm{C}$ a hatching success between 25 and $57 \%$. However, Tilley et al. (2019) reported a hatching success of $71 \%$ at an average temperature of $33{ }^{\circ} \mathrm{C}$. Laloë et al. (2017), indicated for the Cape Verde rookery that by the year 2100 , under the least favorable climate change scenario, hatchlings' emergence success would be reduced to $49.1 \%$.

In addition, nest temperature influences hatchling' locomotor performance (Booth et al., 2012) and increase the frequency of congenital anomalies (Wyneken and Salmon, 2020). These morphological alterations can range from changes in the pattern of carapace scutes which are characteristic to each sea turtle species (Zimm et al., 2017), to other anomalies, such as the absence of a tail, deformations of the carapace, modifications or absence of eyes, and albinism (Wyneken \& Salmon, 2020).

Monitoring nest temperatures and hatching success provides essential information for the conservation and management of sea turtles. Changes in hatching success may indicate variation occurring in some of the influencing factors (Miller et al., 2000). A significant decrease in hatching success over time would lead to reductions in population size (Saba et al., 2012; Santidrián et al., 2015).

Temperature studies in Cuba have been focused on rookeries in the Guanahacabibes Peninsula and the San Felipe Keys (Gerhartz et al., 2018 and Calderón et al., 2020). High temperatures in nests were found in both areas. Also, studies carried out by Azanza et al. (2008) with green turtle in the Guanahacabibes Peninsula, show low embryonic mortality and an emergence success rate over $80 \%$, but with high levels of congenital anomalies. None of these studies attempted to investigate the relationship between nest temperatures and hatching success or phenotypic abnormalities in the hatchlings. Therefore, the objective of this study was to evaluate the influence of nest temperature on hatching success and the incidence of hatchling' phenotypic abnormalities.

\section{Material and Methods}

\section{Study Area}

The work was carried out from 2010 to 2019 during the months of June to September in the Guanahacabibes Peninsula (Fig. 1), one of the most important nesting colonies in southwestern Cuba (Moncada et al., 2011). Two of the index beaches located on the southern coast of the peninsula, Antonio $(21.90 \mathrm{~N}$; -84.66 W) and La Barca $(21.85 \mathrm{~W} ;-84.76 \mathrm{~N})$, were selected (Fig. 1).

\section{Data Collection}

To monitor incubation temperatures, two types of dataloggers (HOBO U12 and Pendant ${ }^{\circledR}$ 8K-UA-001-08) were placed in the center of 14 nests on Antonio Beach and in 34 nests on La Barca Beach. HOBO U12 has an operating range from $20^{\circ}$ to $70^{\circ} \mathrm{C}$ (temperature) and an accuracy of $\pm 0.35^{\circ} \mathrm{C}$ from $0^{\circ}$ to $50^{\circ} \mathrm{C}$ and Pendant ${ }^{\circledR}$ 8K-UA-001-08 has an operating range from $-20^{\circ}$ to $70^{\circ} \mathrm{C}$ and an accuracy of $\pm 0.53^{\circ} \mathrm{C}$ from $0^{\circ}$ to $50^{\circ} \mathrm{C}$. They were introduced during the oviposition and programmed to register every two hours synchronously. All sensor information was downloaded using HOBOware Pro version 3.2.1 software (Onset Computer Corporation). Incubation duration was calculated according to the criteria stated in Calderón et al. (2020): the number of days between the night of laying and the night the first hatchlings emerged (Godley et al. 2002) minus the average number of days (four) that hatchlings spent in the egg chambers. Subsequently, average daily nest temperature and the average over the entire incubation period were calculated for each nest. In addition, each incubation period was divided into three equal thirds for analysis for which the average temperatures were also calculated.

Nest exhumation was performed three days after the emergence of the hatchlings and the number of empty eggs shells and unhatched eggs was counted. Hatching success was defined as the percentage of hatched eggs (assumed from the number of shells) with respect to the total number of eggs in the nest (sum of the number of shells and unhatched eggs). The number of nests that were evaluated for hatching success by seasons is reflected in Table 4 . 


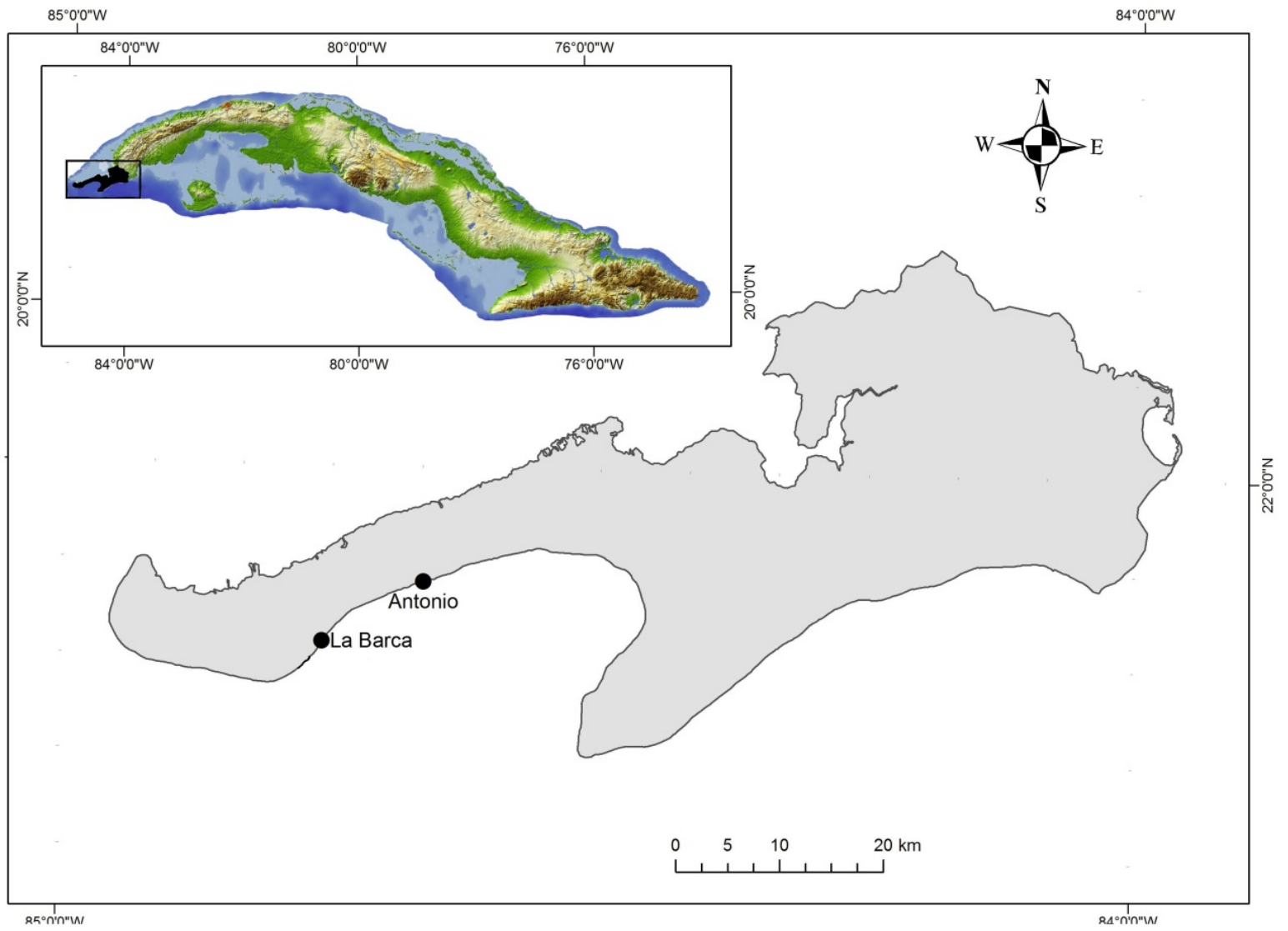

Figure 1. Location of sea turtle nesting beaches in the Guanahacabibes Peninsula National Park and Biosphere Reserve, Cuba. Antonio and La Barca, the index beaches where the study was carried out, are highlighted in black

In order to evaluate the influence of temperature on congenital anomalies, the number of hatchlings with supernumerary vertebral and costal shell scutes and carapace malformations (compressed carapace) was counted in 17 nests with sensors and another set of 109 nests without sensors at La Barca Beach. For each nest, the percentage of hatchlings with each malformation was calculated. These malformations were selected because they are the most frequent in the Guanahacabibes rookeries (Azanza et al., 2008). Hatchlings' morphological anomalies stated above were only related to the temperature of the last third of embryonic development, because according to Miller et al. (2017), it is during this stage that the formation of the shell and scales occur.

\section{Statistical Analysis}

Spearman correlation was used to evaluate the influence of average incubation temperature on hatching success for the entire period and during each incubation third. This test was also used to evaluate relationships between incubation temperature during the last third with the percentages of carapace malformations and supernumerary scutes. Differences in hatching success between seasons were determined with Kruskal-Wallis test followed by a non-parametric means' comparison test. Statistica version 8.0 software was used to carry out the statistical tests with a 0.05 value of significance.

\section{Results and Discussion}

According to Howard et al. (2014), the maximum limit for successful incubation is not adequately defined. In this study, the average temperature of the incubation period was 31.33 $\pm 0.51{ }^{\circ} \mathrm{C}\left(30.5-32.7^{\circ} \mathrm{C}\right)$ while average temperature during the last third of embryonic development was $33.23 \pm 0.76^{\circ} \mathrm{C}$ $\left(32-35^{\circ} \mathrm{C}\right)$. Despite high temperatures, average hatching success per season was higher than $87 \%$, with the exception of the nests of the 2016 in La Barca Beach, (Table 1). With temperature as high as $35^{\circ} \mathrm{C}$ during the last third of incubation, still, two nests in La Barca Beach presented hatching success higher than $94 \%$.

Hatching success reported in this study is higher than in other nesting areas for a given temperature value. Table 2 shows the marked variation in hatching success between incubation temperatures, even in studies carried out on the same nesting 
beaches. A negative correlation was found between the average temperature during the entire incubation and during the last third with hatching success. At La Barca Beach, the relationship found between hatching success and temperature was low, while in Antonio was higher. The temperature of the second third was not related to hatching success on any of the beaches. At the same time, higher temperatures during the first third of embryonic development only caused a decrease in hatching success at Antonio Beach. In both beaches, the temperature of the last third was the one that best explained the decrease in hatching success (Table 3). This is the period of the development with the highest temperatures because of the metabolic heating (Sonmez, 2018).

Table 1. Temperature and hatching success of green turtle nests analyzed by seasons in the Guanahacabibes Peninsula, Cuba

\begin{tabular}{lccccc}
\hline Beach & Nesting season & N & TPI Mean \pm SD & T3 Mean \pm SD & HS Mean \pm SD \\
\hline La Barca & 2014 & 6 & $31.04 \pm 0.44$ & $32.5 \pm 0.54$ & $93.03 \pm 4.38$ \\
& 2015 & 7 & $31.44 \pm 0.60$ & $33.51 \pm 0.91$ & $95.51 \pm 2.72$ \\
& 2016 & 2 & $32.66 \pm 1.12$ & $35.29 \pm 1.52$ & $82.61 \pm 6.20$ \\
& 2017 & 3 & $31.32 \pm 0.47$ & $33.12 \pm 0.71$ & $90.93 \pm 9.14$ \\
& 2018 & 5 & $31.22 \pm 0.31$ & $32.97 \pm 0.67$ & $94.09 \pm 3.34$ \\
Antonio & 2019 & 11 & $31.87 \pm 0.69$ & $34.11 \pm 0.75$ & $90.26 \pm 6.18$ \\
& Total & 34 & $31.59 \pm 0.61$ & $33.58 \pm 0.85$ & $91.07 \pm 5.33$ \\
& 2014 & 4 & $30.87 \pm 0.35$ & $32.43 \pm 0.66$ & $95.45 \pm 3.74$ \\
& 2015 & 1 & 30.96 & 32.64 & 100 \\
& 2016 & 2 & $31.36 \pm 0.89$ & $33.43 \pm 1.33$ & $90.55 \pm 1.34$ \\
& 2018 & 3 & $30.65 \pm 0.28$ & $32.22 \pm 0.67$ & $96.15 \pm 3.16$ \\
& 2019 & 4 & $31.34 \pm 0.45$ & $33.35 \pm 0.60$ & $87.96 \pm 4.76$ \\
& Total & 14 & $31.04 \pm 0.49$ & $32.81 \pm 0.81$ & $94.02 \pm 3.25$ \\
\hline
\end{tabular}

Temperature of the entire incubation period (TPI), incubation temperature during the last third (T3), number of nests $(\mathrm{N})$, hatching success (HS), standard deviation (SD)

Table 2. Hatching success in green turtle nests, reported at different incubation temperatures on different nesting beaches

\begin{tabular}{lccc}
\hline Reference & Location & $\begin{array}{c}\text { TPI } \\
\text { Mean } \pm \text { SD (SEM) }\left({ }^{\circ} \mathbf{C}\right)\end{array}$ & $\begin{array}{c}\text { Hatching Success } \\
\text { Mean } \pm \text { SD }(\%)\end{array}$ \\
\hline Broderick et al. (2001) & Long Beach & $29.5 \pm 0.10$ & $85 \pm 0.16$ \\
Weber et al. (2012) & NEB & $32.2 \pm 0.18$ & $57 \pm 0.23$ \\
& Long Beach & 31 & $<80$ \\
Santidrián et al. (2017) & NEB & 33 & $<60$ \\
Tilley et al. (2019) & Cabuyal, Costa Rica & $31.2 \pm 1.2$ & $87 \pm 19$ \\
& Long Beach & $31 \pm 0.6$ & $91 \pm 7$ \\
Stewart et al. (2020) & NEB & $33 \pm 0.9$ & $71 \pm 18$ \\
\hline
\end{tabular}

Standard deviation (SD); Standard error of the mean (SEM); Temperature of the entire incubation period (TPI)

Table 3. Correlation between incubation temperature, during different stages of embryonic development, and hatching success in green turtle nests in the Guanahacabibes Peninsula, Cuba

\begin{tabular}{lll}
\hline Period & Antonio & La Barca \\
\hline First third & $\mathrm{r}=-0.56^{*}$ & $\mathrm{r}=-0.21 \mathrm{~ns}$ \\
Second third & $\mathrm{r}=-0.23 \mathrm{~ns}$ & $\mathrm{r}=-0.26 \mathrm{~ns}$ \\
Last third & $\mathrm{r}=-0.60^{*}$ & $\mathrm{r}=-0.42^{*}$ \\
Incubation temperature & $\mathrm{r}=-0.49 \mathrm{~ns}$ & $\mathrm{r}=-0.40^{*}$ \\
\hline
\end{tabular}

$* \mathrm{p}<0.05$ 
The decrease in hatching success with the increase in temperature during the first and last third found in Antonio Beach coincides with that found by Weber et al. (2012) in nests of C. mydas and by Kobayashi et al. (2017) in loggerhead (Caretta caretta) nests. These authors found no relationship between the temperature of the second third and the embryonic mortality recorded during this period. Bladow \& Milton (2019) observed an increase in embryonic mortality in green turtle nests only in the final stages of embryonic development, similar to La Barca Beach.

The low relationship found between hatching success and nest temperature at La Barca Beach may be due to the fact that hatching success is influenced by other factors such as water availability (Erb et al., 2018), gas concentrations (Chen et al., 2010), presence of vegetation (Cabrera et al., 2019) and sand grain size (Ackerman, 1977; Stewart et al., 2020).

Hatching success did not show a difference between seasons at La Barca Beach $\left(\mathrm{H}_{(9, \mathrm{~N}=370)}=14.99 \mathrm{p}=0.09\right)$, but there was difference in Antonio Beach $\left(\mathrm{H}_{(6 ; \mathrm{N}=93)}=18.90 ; \mathrm{p}=\right.$ 0.004). At this beach, only the year 2014 differed from 2016 and 2019. In most of the seasons, hatching success was higher than $85 \%$ (Table 4). Miller et al. (2000), suggests that temporary changes in hatching success could be related with changes in abiotic and biotic factors, therefore, lack of variation might be related with stable environment conditions during analyzed seasons. The fact that the increase in nesting temperatures observed in recent years by Calderón et al. (2020) at Guanahacabibes beaches is not equally reflected in hatching success, could be the result, not only of the thermal tolerance of embryos in nests with high temperatures, but the influence of other abiotic factors such as moisture, sand characteristics (Erb et al., 2018) and biotic factors like nest site selection (Weber et al. 2018) that might be compensating the effect of high temperatures.

Hatching success observed per season in Guanahacabibes is higher than reported in many nesting areas (Table 5). Wide ranges of beach characteristics have been evaluated in literature to determine their effect on nest site selection and hatching success (Turkozan et al., 2011; Ditmer \& Stapleton, 2012). In the case of Guanahacabibes, it seems that slope (preventing erosion and nest flooding) together with sand characteristics (color and grain size) guarantee proper embryo development. Vegetation presence and species is also identified as a determinant factor for hatching success in this area (Cabrera et al., 2019).

Table 4. Hatching success per season in green turtle nests on Antonio and La Barca beaches

\begin{tabular}{lccc}
\hline Beach & Nesting season & $\mathbf{N}(\mathbf{N} * \mathbf{1 0 0} /$ total nests of the beach) & Hatching success Mean \pm SD \\
\hline La Barca & 2010 & $40(38.84)$ & $89.36 \pm 13.6$ \\
& 2011 & $44(36.98)$ & $76.06 \pm 32.97$ \\
2012 & $10(9.74)$ & $96.24 \pm 4.21$ \\
2013 & $18(8.11)$ & $91.02 \pm 5.40$ \\
& 2014 & $21(34.4)$ & $87.94 \pm 9.21$ \\
2015 & $100(40.98)$ & $89.59 \pm 11.95$ \\
2016 & $24(21.42)$ & $82.45 \pm 21.06$ \\
2017 & $32(14.29)$ & $87.86 \pm 19.27$ \\
& 2018 & $17(21.79)$ & $90.76 \pm 7.53$ \\
& 2019 & $64(27.11)$ & $86.32 \pm 13.91$ \\
& Total & $\mathbf{3 7 0}$ & $\mathbf{8 7 . 7 6} \pm \mathbf{1 3 . 9 1}$ \\
Antonio & $11(28.20)$ & $86.39 \pm 13.68$ \\
& 2010 & $11(52.38)$ & $95.94 \pm 3.55$ \\
& 2014 & $14(22.95)$ & $88.71 \pm 13.52$ \\
& 2015 & $12(20.33)$ & $84.92 \pm 10.58$ \\
& 2016 & $15(9.67)$ & $87.99 \pm 10.01$ \\
& 2017 & $10(22.73)$ & $93.92 \pm 4.51$ \\
& 2018 & $20(19.42)$ & $81.14 \pm 16.18$ \\
& 2019 & $\mathbf{9 3}$ & $\mathbf{8 8 . 4 3} \pm \mathbf{1 0 . 2 9}$ \\
\hline
\end{tabular}

Standard deviation (SD); Number of nests (N) in parentheses is the percentage that represents the number of nests analyzed with respect to the total nests of the season 
Table 5. Hatching success in green turtle nests by nesting season in different study beaches. Some studies report hatching success and standard deviation (SD), others reflect standard error (SEM), and others only report hatching success

\begin{tabular}{|c|c|c|c|}
\hline Reference & Location & $\begin{array}{c}\text { Hatching success (\%) } \\
\text { Mean } \pm \text { SD } /(\text { SEM) }\end{array}$ & Years monitored \\
\hline \multirow[t]{2}{*}{ Cheng et al. (2008) } & Lanyu Island, Taiwan & $80.7 \pm 27.8$ & $1997-2006$ \\
\hline & Wan-an Island & $72.2 \pm 30.2$ & $1997-2006$ \\
\hline \multirow[t]{5}{*}{ Bellini et al. (2013) } & \multirow[t]{4}{*}{ Atol das Rocas, Brazil } & 72 & 1993 \\
\hline & & 78.6 & 1994 \\
\hline & & 74.1 & 1995 \\
\hline & & 70.1 & 1996 \\
\hline & & 70.1 & 1997 \\
\hline Zárate et al. (2013) & Galápagos Islands & $46 \pm 33.4$ & $2004-2007$ \\
\hline \multirow[t]{3}{*}{ Xavier et al. (2006) } & Cucuyo, México & 92 & 2002 \\
\hline & & 89 & 2003 \\
\hline & & 86 & 2004 \\
\hline Turkozan et al. (2011) & Akyatan, Turkey & $58-67$ & $2006-2009$ \\
\hline Almeida et al. (2011) & Trindade Is, Brazil & $84.4 \pm 21.5$ & --------- \\
\hline Brost et al. (2015) & Florida & $54.9 \pm(8.2)$ & 2002- 2012 \\
\hline \multirow[t]{2}{*}{ Bladow y Milton (2019) } & Boca de ratón, Florida & $54.82 \pm(6.94)$ & 2016 \\
\hline & & $55.02 \pm(2.30)$ & 2017 \\
\hline
\end{tabular}

\section{Effect of Temperature on Malformations}

Many authors have evaluated the effect of biotic and abiotic factors on the morphology of hatchlings. Both the maternal origin and the conditions of the nest influence their morphology (Glen et al., 2003; Booth et al., 2012). On this matter, relocation of nests also impacts embryos morphology. Sonmez (2019) found significant differences in plastral scutes between natural and relocated nests while Sonmez et al. (2011) found significant differences in nuchal, costal and marginal scutes as well as in their straight carapace width, weight, and length of their fore limbs. Congenital malformations can reduce the emergence of hatchlings (Craven et al., 2019). According to Wyneken \& Salmon (2020), if the young successfully emerge from the nest and reach the sea, their survival chances are lower due to the existence of anomalies or other defects caused by high temperatures.

As shown in Figure 2, a positive relationship was found between the temperature presented during the last third of em- bryonic development and the frequency of neonates with supernumerary scutes $(r=0.70 ; p<0.01)$. However, the increase in temperature in the nests of this species did not seem to influence the malformations of the carapace in the neonates $r=$ $-0.22 ; \mathrm{p}>0.05$.

The increase in the number of scutes due to the increase in temperature found in this study coincides with that described by Zimm et al. (2017). The increase in nest temperature increases the speed at which embryonic development occurs resulting in a decrease in the duration of incubation (Miller et al., 2017). This increase in the speed of embryonic development may be the cause of the appearance of errors in the process of formation of the scutes.

Of the 126 nests analyzed, malformations in the carapace were less frequent than supernumerary shells (Table 6). Barcenas-Ibarra et al. (2015) and Azanza et al. (2008) report supernumerary shells as the most frequent anomalies found in this species. 

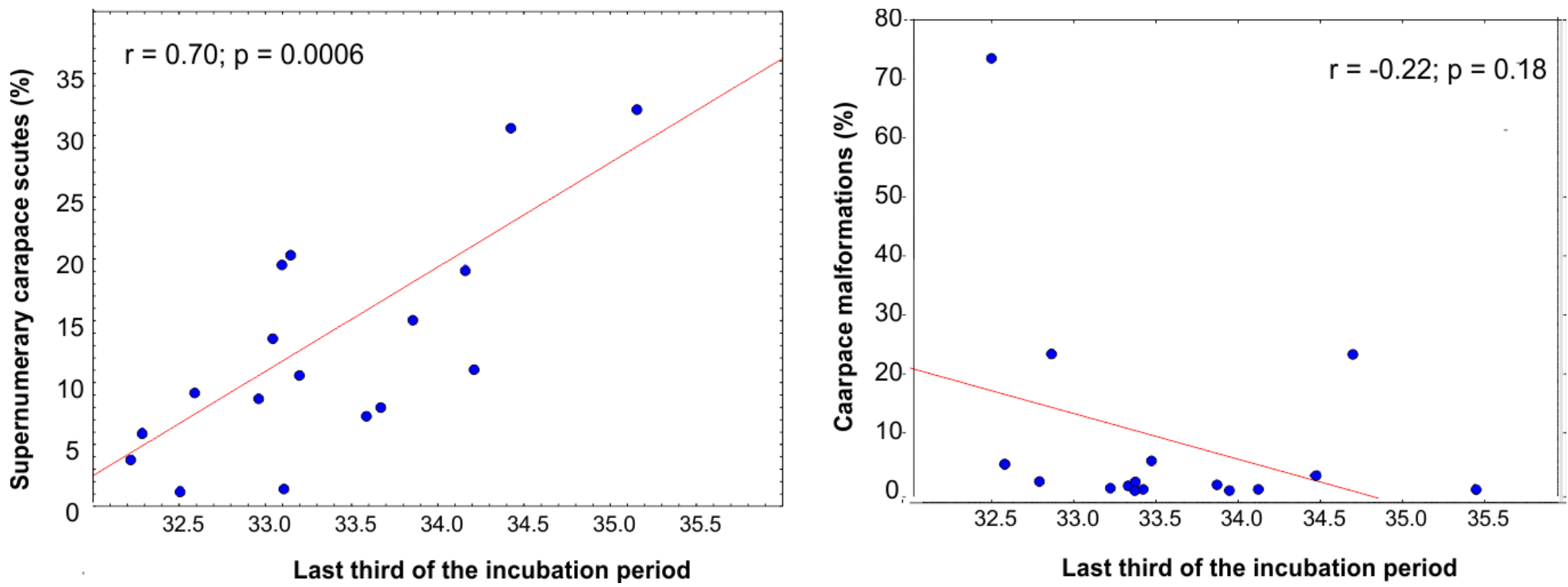

Figure 2. Relationship between the temperature of the last third of embryonic development and the main phenotypic anomalies reported in Guanahacabibes. Left: supernumerary scutes and right: malformations in the carapace

Table 6. Percentage of the most frequent malformations found in Chelonia mydas nests in the Guanahacabibes Peninsula, Cuba

\begin{tabular}{llll}
\hline & Mean \pm SD & Min & Max \\
\hline Carapace malformations (\%) & $2.11 \pm 5.99$ & 0.00 & 41.67 \\
Supernumerary scutes (\%) & $9.16 \pm 14.30$ & 0.00 & 86.11 \\
\hline
\end{tabular}

Standard deviation (SD)

\section{Conclusion}

High hatching success recorded in this study, despite high temperature; demonstrate the thermal resistance of green turtle hatchlings on the beaches analyzed. However, high temperatures, especially last third of embryonic development, did affect hatching success and caused alterations in the characteristic shell pattern of this species.

\section{Compliance with Ethical Standard}

Conflict of interests: The authors declare that for this article they have no actual, potential or perceived conflict of interests.

Ethics committee approval: There was not experimentation with animals in this research since the study was observational. Authorization to access natural areas was provided by the Ministry of Science, Technology and Environment.

Funding disclosure: The Ocean Foundation, the SEE Turtles, and Sea Turtle Conservancy provided for the logistical support of the temperature monitoring program. Guanahacabibes National Park administration provided all the camp logistic in the nesting areas.
Acknowledgments: To the workers and volunteers for their effort in the conservation of marine turtles in Cuba.

\section{Disclosure: -}

\section{References}

Ackerman, R.A. (1977). The respiratory gas exchange of sea turtle nests (Chelonia, Caretta). Respiration Physiology, 31, 19-38.

https://doi.org/10.1016/0034-5687(77)90062-7

Almeida, A.P., Moreira, L.M.P., Bruno, S.C., Thomé, J.C.A., Martins, A.S., Bolten, A.B., Bjorndal, K.A. (2011). Green turtle nesting on Trindade Island, Brazil: abundance, trends, and biometrics. Endangered Species Research, 14, 193-201.

https://doi.org/10.3354/esr00357

Azanza, J., Ibarra, M.E., Ruiz, A., Hernández, J., DíazFernández, R., Hernández, N. (2008). Análisis de nidos de 
tortuga verde (Chelonia mydas) durante la temporada de anidación 2006 en la Península de Guanahacabibes, Cuba. Revista de Investigaciones Marinas, 29(1),61-69.

Bárcenas-Ibarra, A., de la Cueva, H., Rojas-Lleonart, I., Abreu-Grobois, F.A., Lozano-Guzmán, R.I., Cuevas, E., García-Gasca, A. (2015). First approximation to congenital malformation rates in embryos and hatchlings of sea turtles. Birth Defects Research Part A: Clinical and Molecular Teratology, 103(3), 203-224.

https://doi.org/10.1002/bdra.23342

Bellini, C., Santos, A.J.B., Grossman, A., Marcovaldi, M.A., Barata, P.C.R. (2013). Green turtle (Chelonia mydas) nesting on Atol das Rocas, north-eastern Brazil, 1990-2008. Journal of the Marine Biological Association of the United Kingdom, 93(4), 1117-1132.

https://doi.org/10.1017/S002531541200046X

Bladow, R.A., Milton, S.L. (2019). Embryonic mortality in green (Chelonia mydas) and loggerhead (Caretta caretta) sea turtle nests increases with cumulative exposure to elevated temperatures. Journal of Experimental Marine Biology and Ecology, 518, 151180.

https://doi.org/10.1016/j.jembe.2019.151180

Booth, D.T., Feeney, R., Shibata, Y. (2012). Nest and maternal origin can influence morphology and locomotor performance on hatchling green turtles (Chelonia mydas) incubated in field nests. Marine Biology, 160, 127-137.

https://doi.org/10.1007/s00227-012-2070-y

Broderick, A.C., Godley, B.J., Hays, G.C. (2001). Metabolic Heating and the Prediction of Sex Ratios for Green Turtles (Chelonia mydas). Physiological and Biochemical Zoology, 74(2), 161-170.

https://doi.org/10.1086/319661

Brost, B., Witherington, B., Meylan, A., Leone, E., Ehrhart, L., Bagley, D. (2015). Sea turtle hatchling production from Florida (USA) beaches, 2002 - 2012, with recommendations for analyzing hatching success. Endangered Species Research, 27, 53-68.

https://doi.org/10.3354/esr00653

Cabrera-Guerra, C., Azanza-Ricardo, J., BetancourtÁvila, R., Bretos, F., Pérez Álvarez, P. (2019). Influencia de las especies arbustivas sobre el éxito reproductivo de la tortuga verde en la Península de Guanahacabibes, Pinar del Río, Cuba. Revista del Jardín Botánico Nacional, 40, 121130.
Calderón-Peña, R., Betancourt-Avila, R., Rodríguez-Fajardo, E., Martínez-González, Y., Azanza-Ricardo, J. (2020). Sex ratio of the green sea turtle Chelonia mydas (Testudines: Cheloniidae) hatchlings in the Guanahacabibes Peninsula, Cuba. Revista de Biología Tropical, 68(3), 777-784. https://doi.org/10.15517/rbt.v68i3.39033

Cheng, I.J., Dutton, P.H., Chen, C.L., Chen, H.C., Chen, Y.H., Shea, J.W. (2008). Comparison of the genetics and nesting ecology of two green turtle rookeries. Journal of Zoology, 276, 375-384.

https://doi.org/10.1111/j.1469-7998.2008.00501.x

Chen, C.L., Wang, C.C., Cheng, L.J. (2010). Effects of biotic and abiotic factors on the oxygen content of sea turtle nests during embryogenesis. Journal of Comparative Physiology. B, Biochemical, Systemic, and Environmental Physiology, 180, 1045-1055.

https://doi.org/10.1007/s00360-010-0479-5

Craven, K. S., Sheppard, S., Stallard, L. B., \& Richardson, M. (2019). Investigating a link between head malformations and lack of pigmentation in loggerhead sea turtle embryos (Caretta caretta) in the southeastern US. Herpetological Notes, 12, 819-825.

Ditmer, M.A., Stapleton, S.P. (2012). Factors affecting hatch success of hawksbill sea turtles on Long Island, Antigua, West Indies. PloS one, 7(7), e38472.

https://doi.org/10.1371/journal.pone.0038472

Erb, V., Lolavar, A., Wyneken, J. (2018). The role of sand moisture in shaping loggerhead sea turtle (Caretta caretta) neonate growth in southeast Florida. Chelonian Conservation and Biology, 17, 245-251.

https://doi.org/10.2744/CCB-1301.1

Glen, F., Broderick, A.C., Godley, B.J., Hays, G.C. (2003). Incubation environment affects phenotype of naturally incubated green turtle hatchlings. Journal of the Marine Biological Association of the United Kingdom, 83, 1183-1186.

https://doi.org/10.1017/S0025315403008464h

Gerhartz-Muro, J.L., Azanza-Ricardo, J., Moncada, F., Gerhartz-Abraham, M., Espinosa, L., Forneiro, Y., Chacón, D. (2018). Sand and incubation temperatures in a sea turtle nesting beach at the Cayos de San Felipe National Park, Pinar del Río, Cuba, during the 2012-2013 season. Revista de Investigaciones Marinas, 38(2), 45-61. 
Howard, R., Bell, I., Pike, D.A. (2014). Thermal tolerances of sea turtle embryos: current understanding and future directions. Endangered Species Research, 26, 75-86.

https://doi.org/10.3354/esr00636

IPCC (2018). Summary for Policymakers. In IPCC, M. Allen, M. Babiker, Y. Chen, H. de Coninck, S. Connors, et al. (Eds.), Global Warming of 1.5 C: An IPCC Special Report on the impacts of global warming of $1.5 \mathrm{C}$ above pre-industrial levels and related global greenhouse gas emission pathways, in the context of strengthening the global response to the threat of climate change, sustainable development, and efforts to eradicate poverty, 1-32, Geneva: World Meteorological Organization.

Kobayashi, S., Wada, M., Fujimoto, R., Kumazawa, Y., Arai, K., Watanabe, G., Saito, T. (2017). The effects of nest incubation temperature on embryos and hatchlings of the loggerhead sea turtle: Implications of sex difference for survival rates during early life stages. Journal of Experimental Marine Biology and Ecology, 486, 274-281.

https://doi.org/10.1016/j.jembe.2016.10.020

Laloë, J.O., Esteban, N., Berkel, J., Hays, G.C. (2016). Sand temperatures for nesting sea turtles in the Caribbean: Implications for hatchling sex ratios in the face of climate change. Journal of Experimental Marine Biology and Ecology, 474, 92-99.

https://doi.org/10.1016/j.jembe.2015.09.015

Laloë, J.O., Cozens, J., Renom, B., Taxonera, A., Hays, G.C. (2017). Climate change and temperature-linked hatchling mortality at a globally important sea turtle nesting site. Global Change Biology, 23(11), 4922-4931.

https://doi.org/10.1111/gcb.13765

Miller, J.D. (1997). Reproduction in sea turtles. In: Lutz PL, Musick JA (eds) The biology of sea turtles. CRC Press, Boca Raton, FL, p 51-80. ISBN: 0-8493-8422-2

Miller, J.D., Mortimer, J.A., Limpus, C.J. (2017). A field key to the developmental stages of marine turtles (Cheloniidae) with notes on the development of Dermochelys. Chelonian Conservation and Biology, 16(2), 111-122.

https://doi.org/10.2744/CCB-1261.1

Moncada Gavilán, F., Nodarse Andreu, G., Azanza Ricardo, J., Medina, Y., Forneiro Martín-Viaña, Y. (2011). Principales áreas de anidación de las tortugas marinas en el archipiélago cubano. Revista electrónica de la Agencia de Medio Ambiente, 11(20), 1-8.
Saba, V.S., Stock, C.A., Spotila, J.R., Paladino, F.V., Tomillo, P.S. (2012). Projected response of an endangered marine turtle population to climate change. Nature Climate Change, 2 (11), 814-820.

https://doi.org/10.1038/nclimate1582

Santidrián - Tomillo, P., Genovart, M., Paladino, F.V., Spotila, J.R., Oro, D. (2015). Climate change overruns temperature resilience in sea turtles and threatens their survival. Global Change Biology, 21(8), 2980-2988.

https://doi.org/10.1111/gcb.12918

Santidrián - Tomillo, P., Fonseca, L., Paladino, F.V., Spotila, J.R., Oro, D. (2017). Are thermal barriers "higher" in deep sea turtle nests? PLoS ONE, 12(5), e0177256.

https://doi.org/10.1371/journal.pone.0177256

Stewart, T.A., Booth, D.T., Rusli, M.U. (2020). Influence of sand grain size and nest microenvironment on incubation success, hatchling morphology and locomotion performance of green turtles (Chelonia mydas) at the Chagar Hutang Turtle Sanctuary, Redang Island, Malaysia. Australian Journal of Zoology, 66(6), 356-368.

https://doi.org/10.1071/ZO19025

Sonmez, B., Turan, C., Özdilek, S.Y. (2011). The effect of relocation on the morphology of Green Turtle, Chelonia mydas (Linnaeus, 1758), hatchlings on Samandag beach, Turkey (Reptilia: Cheloniidae). Zoology in the Middle East, 52, 29-38.

https://doi.org/10.1080/09397140.2011.10638476

Sonmez, B. (2018). Relationship between Metabolic Heating and Nest Parameters in Green Turtles (Chelonia mydas, L. 1758) on Samandağ Beach, Turkey. Zoological Science, 35(3), 243-248.

https://doi.org/10.2108/zs180003

Sonmez B. (2019). Head and plastron scalation patterns of the green turtle, Chelonia mydas, hatchlings in natural and relocated nests on Samandağ Beach. Journal of Black Sea/Mediterranean Environment, 25, 280-293.

Tilley, D., Ball, S., Ellick, J., Godley, B.J., Weber, N., Weber, S.B., Broderick, A.C. (2019). No evidence of fine scale thermal adaptation in green turtles. Journal of Experimental Marine Biology and Ecology, 514, 110-117. https://doi.org/10.1016/j.jembe.2019.04.001 
Turkozan, O., Yamamoto, K., Yilmaz, C. (2011). Nest site preference and hatching success of green (Chelonia mydas) and loggerhead (Caretta caretta) sea turtles at Akyatan Beach, Turkey. Chelonian Conservation and Biology, 10, 270-275.

https://doi.org/10.2744/CCB-0861.1

Weber, S.B., Broderick, A.C., Groothuis, T.G., Ellick, J., Godley, B.J., Blount, J.D. (2012). Fine-scale thermal adaptation in a green turtle nesting population. Proceedings. Royal Society B, 279, 1077-1084.

https://doi.org/10.1098/rspb.2011.1238

Wyneken, J., Salmon, M. (2020). Linking Ecology, Morphology, and Behavior to Conservation: Lessons Learned from Studies of Sea Turtles. Integrative and Comparative Biology, 60(2), 440-455.

https://doi.org/10.1093/icb/icaa044
Xavier, R., Barata, A., Cortez, P.L., Queiroz, N., Cuevas, E. (2006). Hawksbill turtle (Eretmochelys imbricata Linnaeus, 1766) and Green turtle (Chelonia mydas Linnaeus, 1754) nesting activity (2002-2004) at El Cuyo Beach, Mexico. Amphibia-Reptilia, 27, 539-547.

https://doi.org/10.1163/156853806778877077

Zárate, P., Bjorndal, K.A., Parra, M., Dutton, P.H., Seminoff, J.A., Bolten, A.B. (2013). Hatching and emergence success in green turtle Chelonia mydas nests in the Galápagos Islands. Aquatic Biology, 19(3), 217-229.

https://doi.org/10.3354/ab00534

Zimm, R., Bentley, B.P., Wyneken, J., Moustakas-Verho, J.E. (2017). Environmental causation of turtle scute anomalies in ovo and in silico. Integrative and comparative biology, 57(6), 1303-1311.

https://doi.org/10.1093/icb/icx066 